\title{
Basic principles for the identification of landslides using geophysical methods
}

\author{
Zenon Pilecki ${ }^{*}$ \\ ${ }^{1}$ Mineral and Energy Economy Research Institute, Polish Academy of Sciences, 31-261 Krakow, \\ Poland
}

\begin{abstract}
Cases of damage to structures in landslide areas in Poland, and sometimes construction catastrophes, occur most frequently in periods of intense precipitation (e.g. in 1997, 2000, 2002 and 2010). The greatest landslide risk occurs in mountainous areas in the Flysch Carpathians, and the number of landslides posing major problems exceeds 20,000. Terrain surface relief and geological structure including the tectonics, properties of the geological medium, presence of excessive water mostly due to intense precipitation, and human activity have an impact on landslide risk. This paper is aimed at presenting basic principles for the geophysical identification of landslides gained from experience in various regions of Poland, particularly in the flysch formations in the Carpathian Mountains. The geophysical methods which are of the greatest importance in the study of landslides are specified. Their advantages and limitations are presented. The principles of geophysical methods applied at the stage of designing and implementing research, processing and interpreting data, analysis of results, and their documentation are discussed.
\end{abstract}

\section{Introduction}

Recognition of landslide risk has been the subject of much research work. Cruden and Varnes [1], Dikau et al. [2], and Roy [3] described interesting presentations of landslide processes and landslide classifications. Similar issues concerning the conditions of landslides in Poland were presented by Kleczkowski [4], Bober [5], Thiel [6], Zabuski et al. [7], Bober and Thiel [8], Rybicki et al. [9], Wiłun [10], Borecka et al. [11].

Landslide areas are difficult to use for construction purposes [12]. In Poland, cases of damage to buildings occur, sometimes involving catastrophic impacts on structures, most frequently in periods of intense precipitation (e.g. in 1997, 2000, 2002 and 2010). The greatest risk of landslides occurs in mountainous areas in the Flysch Carpathians, and the number of landslides posing major problems exceeds 20,000 [13, 14] (Fig. 1). The existence of such a large number of recorded landslides in this area is influenced by the terrain surface relief and the geological structure including tectonics, the properties of the geological medium, the presence of excessive water mostly due to intense precipitation, and human activities. There are occasional earthquakes in the Beskid Żywiecki and in the Pieniny Mountains which also influence the activation of landslides [13].

\footnotetext{
*Corresponding author: pilecki@meeri.pl
} 


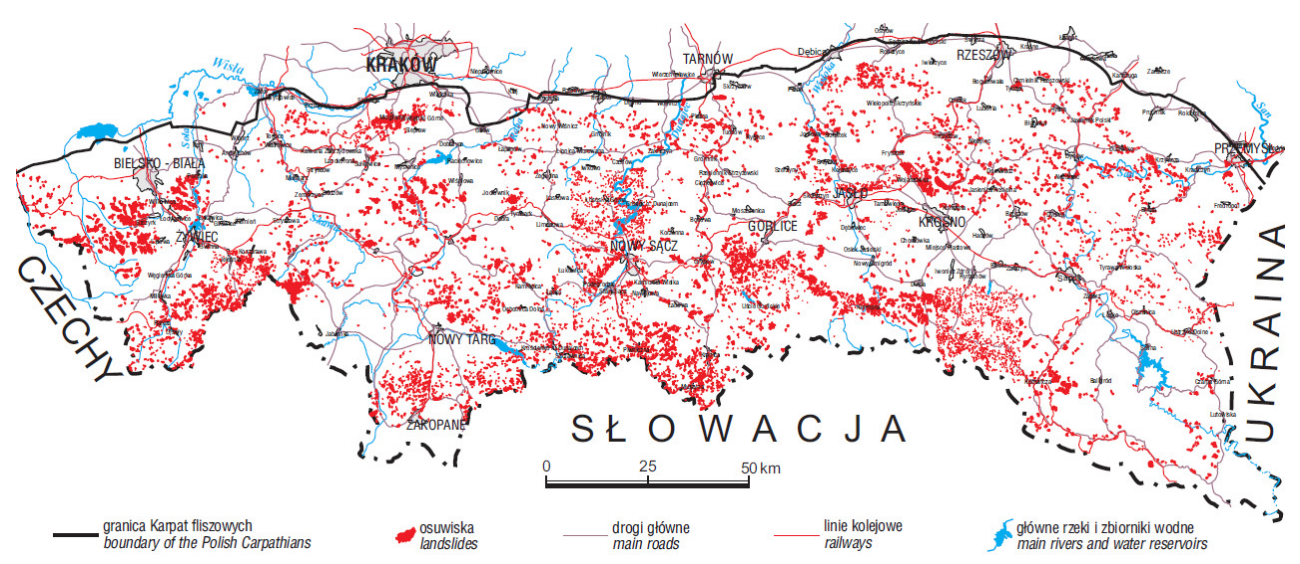

Fig. 1. Map of landslides in the Polish Flysch Carpathians compiled from data from the Polish Geological Institute updated to the end of 2000 [14].

Under the conditions found in the Flysch Carpathians, it should be emphasised that there is a scientific and practical need to develop a geophysical method for identifying the risk of landslides because:

1. The method of recognising landslide processes under the conditions in the Flysch Carpathians is primarily by geodetic, inclinometric and piezometric measurements. In the last two decades, geophysical methods have become more and more widespread, but their use has mainly been experimental.

2. The fast development of geophysical equipment and specialised software enables 3D/4D geophysical models, more attractive for engineering purposes, to be developed. These results, however, require proper presentation and analysis in a manner that can be understood by the construction engineer.

3. Geophysical information can be helpful at every stage of making construction decisions.

Jongmans and Garambois [15] presented an interesting diagnosis of the relatively limited use of geophysical methods in identifying landslide hazards. They found that geophysical methods provide images in terms of physical parameters, which are not directly linked to the geological and mechanical properties required by geologists and engineers. Another reason comes from a tendency among some geophysicists to overestimate the quality and reliability of the results. Undoubtedly, these statements are relevant to much geophysical work, so it is important to continually emphasise the principles behind proper identification of hazards using geophysical means.

This paper is aimed at presenting the basic principles of geophysical identification of landslides. It specifies the geophysical methods which are of greatest importance in the study of landslides. Their advantages and limitations are presented. The principles of the geophysical methods applied at the stage of designing and carrying out measurements, processing and interpreting data, analysis of results and their documentation are described.

\section{Geophysical methods used for landslide identification}

Usually the identification of landslides by geophysical methods is presented worldwide in terms of the results of measurements on various types of landslides. Jongmans and Garambois [15] classified these applications in terms of two general objectives:

1. Locating the boundaries of geophysical contrast within the geological medium affected by slide processes including the failure surfaces. Four main different possibilities are considered : 
- The geophysical contrasts are of lithological origin (layering or pre-slide weathering), and the failure surface mainly coincides with a geological interface or layer. These features range from local fracture zones to larger regional structural features. Joints, fractures and fault zones may be dry, fluid-filled or filled with clays or weathered rock. The detectability of these features increases with the size of the feature and with the presence of distinctive pore fluids or conductive fill material.

- Geophysical contrasts are also controlled by lithological variations, but the failure surface cuts the structure in a more complex way and may or may not be deduced from the geophysical image depending on the landslide activity, the heterogeneity of the geological medium and the resolution of the technique.

- The failure surface or presumed failure surface is mainly detected by geophysical propagation methods.

- Geophysical contrast arises between the slide and the unaffected mass arising from the cumulative or separate actions of displacement, weathering and an increase in water content.

2. Recognition of water content within the geological medium affected by slide processes, for which electrical and electromagnetic methods were usually applied.

The identification of landslides using geophysical methods has been the subject of many publications that deal with this issue in a more general way, e.g. Bogoslovsky and Ogilvy [16], Mc Cann and Foster [17], Caris et al. [18], Hack [19], and Jongmans and Garambois [15]. It should be emphasised that the approach by which this issue is presented in these publications is different due to the intensive development of equipment and the processing and interpretation of geophysical data over the last few decades.

In the specific conditions of the flysch formations in the Polish section of the Carpathians, geophysical methods are most frequently used in the identification of such geological and hydrogeological elements as:

- Courses of probable slip surfaces, which can also be seen as the border between contrasting physical properties in the geological medium. These boundaries usually occur at the contact of a less weathered rock basement with a more weathered upper part, most often affected by landslide processes.

- Geophysical boundaries, including lithological or larger fractures meeting the criterion of contrasting properties in a geological medium.

- The location of the ground water table and the impact of waterlogging on the formation of the slip surface.

- Weak zones characterised by unfavourable spatial variations of physical properties in the geological medium, such as waterlogged zones, intense fracturing, slide mass affected by landslide processes, etc.

Landslides are one of the most difficult geophysical issues due to their many causes and the complex nature of the landslide process. Under geological-engineering conditions in relation to typical landslides in Poland, the most important geophysical methods used are:

- Ground Penetrating Radar (GPR) in the 2D/3D/4D profiling scheme,

- Seismic survey via 2D/3D/4D refraction profiling, seismic tomography, multichannel surface analysis (MASW),

- Electrical Resistivity Profiling (ERP) in the 2D/3D/4D profiling scheme, Vertical Electrical Sounding (VES), and Electrical Resistivity Tomography (ERT).

Examples of such research are: Bestyński and Trojan [20], Ślusarczyk [21], Dziewański and Pilecki [22], Karczewski and Ziętek [23], Pilecki et al. [24, 25], Bednarczyk [26], Ostrowski et al. [27], Kamiński et al. [28], Harba and Pilecki [29].

These methods were also highlighted as the most important ones used in recognising the structure and properties of soils and rocks by the American Association for Testing and 
Materials [30], reapproved in 2011 [31]. Other examples are the use of geophysical methods such as: reflection seismics, seismic interferometry, borehole tomography methods, and magnetic or self-potential methods. There have also been great developments in remote sensing techniques over the last dozen years or so.

\section{Basic advantages and disadvantages of geophysical methods}

Geophysical methods are used for non-invasive investigation of the properties and structure of a geological medium and the physical processes taking place within it. The non-invasive nature of this investigation indicates that there is no need for direct access to the geological medium, e.g. by borehole or other excavation. Depending on the kind of geophysical method, different properties of the geological medium are investigated: electromagnetic, elastic, electric, magnetic, physical-mechanical and other. In order to have the possibility of recognising borders with distinct properties, contrast is an important element in geophysical investigations.

Geophysical methods have their advantages and limitations [32]. The main advantages of these methods are as follows:

- They are efficient, as they allow for relatively large areas to be surveyed relatively quickly and continuously in comparison with, for example, local (one point) boreholes. Geophysical studies should be financially more attractive than a set of boreholes or other excavations.

- They are non-invasive, because they do not require invasive access to the geological medium. They are carried out on the terrain surface or via excavation, if possible.

- They are multi-informative, as they use different physical fields. Therefore it is possible to describe the geological medium in a variety of complementary types of information. If one performs a series of measurements on the same profile at different intervals of time, it is possible to investigate the development of the landslide process.

- The penetration depth varies depending on the geophysical method used and its methodology. Geophysical surveys carried out for landslide recognition are directed towards identifying the geological medium to a depth of ten metres or so and, if necessary, to a few tens of metres, which is generally sufficient to design a protective structure for the landslide.

- Resolution, as in the case of penetration depth, this varies depending on the geophysical method used and its methodology. For the basic geophysical methods: GPR, seismic, and electrical methods, greater resolution results in less depth of penetration.

The main disadvantages of geophysical methods are as follows:

- The ambiguity of the results of geophysical interpretations requires them to be correlated with geological-engineering information, or with the results from other geophysical measurements. At least two complementary geophysical methods are suggested.

- Geophysical recordings are sensitive to various types of disturbance during measurement.

- Geophysical images are of limited resolution, particularly with increased distance from the source (transmitting antenna, vibration source or current electrode). In the case of active geophysical methods there is a compromise between resolution and depth to which identification is attempted. In the case of passive methods there is ambiguity in the identification of features because an 
object at a particular depth can generate a similar anomaly to a larger object at a greater depth.

- The time required for processing and interpretation of the geophysical data varies and is often difficult to determine. It depends on the type of geophysical method used and the measurement conditions. For more complicated tasks, this time can be extended, resulting in higher costs.

It is worth underlining that the theoretical principles behind geophysical methods are quantitative, however when actually applied, they often yield interpretations that are qualitative [31]. Some geophysical methods provide data from which a preliminary interpretation can be made in the field, for example GPR. Some methods require that the data should be processed before any quantitative interpretation can be made, for example, seismic refraction.

Geophysical methods can be used in two situations in relation to landslide identification: (1) in an initial investigation of the landslide hazard (2) to confirm the anomalies provided by other measurements or to provide additional information.

Geophysical analysis must be conducted by a competent professional to ensure that it is consistent with geological-engineering conditions.

In summary, it should be emphasised that geophysical methods provide special information that cannot be obtained by other methods. Jongmans and Garambois [15] stated that almost all the advantages of geophysical methods correspond to the disadvantages of geotechnical techniques and vice versa.

\section{Basic principles of geophysical identification of landslides (on the basis of [32])}

Appropriate methodologies for geophysical measurement and for processing and interpretation of geophysical data should be properly designed to achieve the most informative results.

At the stage of design and realisation of geophysical measurements, the following principles are suggested:

a) Initially identify the research tasks involved, including the scope of the research and collect available geological-engineering and geophysical information about the study area. Site inspection is also required to assess the measurement conditions.

b) Specify the type of geophysical methods which are most effective in solving the research task involved when considered the conditions under which measurements will take place. One should select geophysical methods in which the cost of acquiring geophysical information is cost-effective compared to other methods. In designing the measurement methodology, it is important to note that:

$\checkmark$ The choice of geophysical method depends on the ability to distinguish different types of borders and weak zones in the geological medium.

$\checkmark \quad$ The results of the measurement should be validated with geological-engineering information coming from, for example, an archival borehole. If necessary, a borehole should be made for data comparison.

$\checkmark$ A method should be selected that is not susceptible to measurement disturbances and which cannot be reduced satisfactorily at the processing stage. In difficult conditions of strong measurement disturbances, it is advisable to perform test measurements together with test processing and interpretation of the data recorded.

$\checkmark \quad$ To solve the research task using geophysical methods one should try to apply at least two methods based on different properties of the medium being examined. The application of one geophysical method is associated with a high risk of 
ambiguity in analysis. This ambiguity can be reduced by taking into account the results available from archival investigations, including data from different excavations and the results from using other methods, during the processing and interpretation process.

c) Design an interpretation methodology in accordance with the measurement conditions and determine how to document the results of the investigation.

d) Carry out the geophysical investigation project including the methodology of measurement, processing and interpretation together with the presentation of final results. The project must be submitted to the contractor.

e) When carrying out geophysical surveys, measurement profiles or measuring points should be determined by the geodetic method. Sufficient accuracy in identifying the location of the measuring point is achieved by means of GPS and measuring tape. General information about the measurements (date, profile number, location, etc.), regardless of their recording in the memory of the measuring equipment, should be written in the operator's notebook.

The following principles are suggested at the geophysical data processing and interpretation stage, during analysis of the final results, as well in their documentation:

a) Field registrations should be organised and archived in the computerised database in clearly-described directories. These data can be used, for example, for reinterpretation.

b) Data processing should primarily aim at improving the signal-to-noise ratio.

c) Data interpretation, usually associated with inverse procedures used for the description of the geological medium with the help of mathematical models, should match (satisfy) the field data. The measure of the quality of the calculations should be the fit of the theoretical model to the field data.

d) Visualisation of the results of the calculations should be legible and understandable for other interested professionals.

e) Comprehensive analysis of the results of the investigation should be made taking into account all the available information, using their own and archival data. On the basis of the analysis, conclusions are drawn from studies that are relevant to further decision making, including engineering for the design of structures to provide protection against landslides. An important part of the analysis is information about the errors involved in and limitations of the geophysical method used.

f) The documentation should be understandable to the construction engineer or other specialist. The description of the measurement methodology and interpretation methodology should be presented in such a way that the investigation can be repeated on the basis of this description.

\section{Summary}

This paper presents the basic principles for the identification of landslides in Poland by geophysical methods, particularly in the flysch formations of the Polish Carpathian Mountains.

In the specific conditions of the Flysch Carpathians, geophysical methods are most frequently used for the identification of the presumed slip surface, lithological boundaries or larger fractures fulfilling the criterion of contrast in physical properties of the geological medium, the location of the groundwater table and the impact of waterlogging on the formation of slip surfaces, and the location of weak zones characterised by unfavourable spatial variations in the properties of the medium, e.g. zones of waterlogging, intensive fracturing, zones affected by slide processes, etc. The recognition and analysis of all these problems by traditional geotechnical methods is often impossible. 
It is stressed in the paper, that appropriate methodologies of geophysical measurement and for the processing and interpretation of the geophysical data should be properly designed to achieve the most informative results.

In the last two decades, the rapid development of geophysical equipment and specialised software has enabled the presentation of ever more attractive 2D geophysical models, and increasingly 3D and 4D models. These models are increasingly attractive for engineering purposes, particularly in time-lapse mode.

This paper also emphasises that each geophysical method also has its advantages and limitations, which have to be provided for in assessing their reliability in site identification.

\section{References}

1. D.M. Cruden, D.J. Varnes, Landslide Types and Processes, Special Report, Transportation Research Board, National Academy of Sciences 247, 36-75 (1996)

2. R. Dikau, D. Brundsen, L. Schrott, M.-L. Ibsen, Landslide recognition: identification, movement and causes (Wiley, Chichester, UK, 1996)

3. R. C. Sidle, H. Ochiai, Landslides: processes, prediction, and land use, Water Resources Monograph 18 (American Geophysical Union, Washington, 2006)

4. A. Kleczkowski, Osuwiska i zjawiska pokrewne (Wyd. Geologiczne, Warsaw, 1995)

5. L. Bober, Rejony osuwiskowe w polskich Karpatach fliszowych i ich zwiazek z budowa geologiczna regionu, Biul. Inst. Geologicznego 340, XXIII, 115-162 (1984)

6. K. Thiel (editor), Właściwości fizyko-mechaniczne i modele masywów skalnych polskich Karpat fliszowych, Hydrotechnika 19 (Publ. Institute of Hydroengineering PAS, Gdańsk, 1995)

7. L. Zabuski, L. Bober, K. Thiel, Osuwiska we fliszu Karpat polskich (Publ. Institute of Hydroengineering PAS, Gdańsk, 1999)

8. L. Bober, K. Thiel, L. Zabuski, Zjawiska osuwiskowe w polskich Karpatach fliszowych. Geologiczno-inżynierskie wtaściwości wybranych osuwisk (Publ. Institute of Hydroengineering PAS, Gdańsk, 1997)

9. S. Rybicki, W. Margielewski, A. Domagała, Landslide on Palenica Mt near Szczawnica (Pieniny Klippen Belt) and their connection with extrema rains in July 1997, Przegląd Geologiczny 46, 11, 1162-1170 (1999)

10. Z. Wiłun, Zarys geotechniki (Wyd. Komunikacji i Łączności, Warsaw, 2000)

11. A. Borecka, M. Cała, J. Flisiak, M. Kowalski, P. Krokoszyński, J. Maciaszek, Z. Pilecki, S. Rybicki, H. Woźniak, Metody badania, monitorowania i stabilizacji osuwisk (AGH University of Science and Technology Press, to be published)

12. Z. Pilecki, J. Kłosiński, E. Pilecka, J. Karczewski, J. Ziętek, Wpływ zawodnienia osuwiska na rozpoznanie granic jego nieciagłości metodami falowymi, Gospod. Surowcami Min. 24, 2/3, 427-444 (2008)

13. W. Rączkowski, Osuwiska polskich Karpat fliszowych, 259-262 (Przew. 72 Zjazdu Pol. Tow. Geol. MAEGS-12, Kraków, 2001)

14. D. Poprawa, W. Rączkowski, Osuwiska Karpat, Przegląd Geologiczny 51, 8, 685-692 (2003)

15. D. Jongmans, S. Garambois, B. Soc. Geol. Fr. 178, 2, 101-112, (2007) doi: 10.2113/gssgfbull.178.2.101

16. V.A. Bogoslovsky, A.A. Ogilvy, Geophysics, 42, 562-571 (1997) doi: 10.1190/1.1440727 
17. D.M. Mc Cann, A. Forster, Eng. Geol., 29, 59-78 (1990) doi: 10.1016/00137952(90)90082-C

18. J.P.T. Caris, Th.W.J. Van Asch, Eng. Geol., 31, 249-276 (1991) doi: 10.1016/00137952(1)90011-9

19. R. Hack, Surv. Geophys. 21, 423-448 (2000) doi: 10.1023/A:1006797126800

20. Z. Bestyński, J. Trojan, Metody geofizyczne w badaniach stateczności zboczy skalnych, Mat. Badawcze seria specjalna nr 4 (Institute of Meteorology and Water Management - National Research Institute, Warsaw, 1975)

21. R. Ślusarczyk, Możliwości zastosowania geofizyki inżynierskiej w problematyce budownictwa ladowego $i$ wodnego, 109-124 (Geofizyka w inżynierii i ochronie środowiska, Dębe near Warsaw, 2001)

22. J. Dziewański, Z. Pilecki, Ocena warunków geologiczno-inżynierskich na terenie powierzchniowych ruchów masowych na przyktadzie osuwiska $w$ Zgłobicach, Studia, Rozprawy, Monografie 109, (Publ. Mineral and Energy Economy Research Institute PAS, Krakow, 2002)

23. J. Karczewski, J. Ziętek, Wykorzystanie metody georadarowej w geofizyce środowiska, Publ. of the Inst. of Geoph. Polish Academy of Science, M-27, 352, 223-232 (2002)

24. Z. Pilecki, J. Ziętek, J. Karczewski, E. Pilecka, J. Kłosiński, The effectiveness of recognizing of failure surface of the Carpathian flysch landslide using wave methods, Proc. 13th European Meeting of Environmental and Engineering Geophysics P48, 1-5 (Istanbul, 03 September 2007)

25. Z. Pilecki (editor), E. Popiołek, J. Karczewski, J. Ziętek, J. Kłosiński, A. Baranowski, E. Pilecka, Ł. Ortyl, J. Pszonka, K. Krawiec, Wpływ rozdzielczości metod falowych na efektywność rozpoznania granic nieciagłości osuwiska (Publ. Agencja WydawniczoPoligraficzna „ART-TEKST”, Krakow, 2008)

26. Z. Bednarczyk, Ground Penetrating Radar (GPR) scanning in geological and geotechnical recognition of mountain site, 731-738 (22 SAGEEP Symposium, Fort Worth, Texas USA, EEGS, US Army Research Office, 2009)

27. S. Ostrowski, B. Rybak-Ostrowska, M. Lasocki, Wykorzystanie przypowierzchniowych badań geofizycznych $w$ rozpoznaniu budowy geologicznej na przyktadzie stref osuwiskowych w Karpatach, Przegląd Geologiczny 61, 1, 67-73 (2013)

28. M. Kamiński, P. Zientara, M. Krawczyk, Wykorzystanie tomografii elektrooporowej do badania osuwisk - osuwisko Dzianisz (potudniowo-zachodnie Podhale). Przegląd Geologiczny 62, 4, 198-2003 (2014)

29. P. Harba, Z. Pilecki, Landslides 14, 3, 1225-1233, doi:10.1007/s10346-016-0779-2 (2016)

30. ASTM, Standard Guide for Selecting Surface Geophysical Methods, Designation D6429 (Philadelphia, 1999)

31. ASTM, Standard guide for selecting surface geophysical methods, Designation: D6429-99, American Society for Testing Materials (Philadelphia, 2011)

32. Z. Pilecki, E. Pilecka, Podstawowe zasady stosowania metod geofizycznych $w$ badaniu osuwisk $i$ terenów zagrożonych osuwiskami, Zeszyty Naukowe - Bulletin of the Mineral Energy Economy Research Institute of the Polish Academy of Sciences 92, $131-140$ (2016) 